\title{
High Growth Firms, Jobs and Peripheral Regions: The Case of
}

\section{Scotland}

Abstract.

High growth firms (HGFs) are expected to be a major source of job creation during the economic recovery. This has prompted a shift in enterprise policy in many countries away from supporting startups and in favour of the promotion of HGFs. However this approach may be less effective in promoting new jobs and economic development in peripheral regions. This issue is addressed by a study of HGFs in Scotland. The origin and characteristics of Scottish HGFs differ in a number of respects from the stylized facts in the literature. Scottish HGFs create less employment than their counterparts elsewhere in the UK. Most Scottish HGFs have a significant physical presence outside of Scotland, thereby reducing their Scottish 'footprint' and domestic job creation. Scottish HGFs appear to have a high propensity to be acquired, increasing their susceptibility to head office closure. The paper concludes that the tendency towards 'policy universalism' in the sphere of entrepreneurship policy is problematic.

Key words: high growth firms, gazelles, entrepreneurship, regional development, Scotland 


\section{INTRODUCTION}

As the economies of Europe and North America slowly emerge from the 'Great Recession' the priority for governments is to stimulate a job-rich economic recovery across all regions and localities. However, in the UK the economic recovery is resulting in a further widening of existing regional disparities. Having performed worse during the recession than London (Champion and Townsend, 2013), second tier cities - many of which are in northern regions - are now lagging behind London in terms of job creation during the recovery (Townsend and Champion, 2013; Centre for Cities, 2014). This has prompted calls for a rebalancing of the economy both sectorally (less dependence on financial services) and geographically. In the recession of the early 1980s governments focused on the small business sector as a source of new jobs. In this recession, in contrast, both national and regional governments in the UK, and in other countries, have switched their focus to high growth firms (HGFs) as a strategy for creating new jobs and fostering economic recovery (Mason and Brown, 2013; Coad et al, 2014). Indeed, HGFs have been deemed 'vital' to the UK's economic recovery' (Hutton and Lee, 2012, p. 331).

This emphasis on HGFs has arisen for two reasons. First, it has been claimed that subsidising business start-ups has proved to be both costly and ineffective, "lead[ing] people to start marginal businesses that are likely to fail, have little economic impact, and generate little employment," (Shane,2009, p. 158). Second, HGFs have been shown to create jobs. A meta-analysis of prior empirical studies concluded that "a few rapidly growing firms generate a disproportionately large share of all net new jobs compared with non-high growth firms. This is a clear-cut result... [T]his is particularly pronounced in recessions when Gazelles continue to grow" (Henrekson and Johansson (2010, p. 240). A UK study based on the Office of National Statistics (ONS) Inter-departmental Business Register (IDBR) - the Business Structure Database - using the OECD definition of high growth, covering the period 2002-2008, found that HGFs represented about $6 \%$ of the total number of businesses but created 54\% of all net new jobs in the UK (Anyadike-Danes et al, 2009). The majority of these HGFs were small (less than 50 employees) but well established (over five years old). 
HGFs have continued to be an important source of jobs during the recession ( Anyadike-Danes et al, 2013; Hart and Anyadike-Danes, 2014), although this contribution has declined compared with the pre- recession period (Hart and Anyadike-Danes, 2014). However, taking a longer term perspective to reflect the episodic nature of growth, analysis of a cohort of start-ups over a 15 year period between 1998 and 2013 identified a very small proportion as being as "extraordinary prolific job creators", accounting for about $40 \%$ of all the jobs created by firms which were still operating in 2013 (Hart and Anyadike-Danes, 2014. The original assertion made by David Birch (1981) - that a small proportion of firms contribute disproportionately to job creation - therefore continues to be valid.

HGFs have several other positive attributes in addition to their propensity to create large numbers of jobs, including above average levels of productivity growth (Du et al, 2013), high levels of innovation (Mason et al, 2012), strong levels of export-orientation (Parsley and Halabishy, 2008) and a high level of internationalisation (Brown and Mawson, forthcoming). Moreover, these firms do not only create jobs directly; they also have important spill-over effects that are beneficial to the growth of other firms in the same locality and industrial cluster (Feldman et al, 2005). Hence, as Storey and Greene (2010, p. 208) observe: "there is little doubt that small businesses that become middle-sized and ultimately large businesses, over a comparatively short period of time, are central to economic prosperity.... Ultimately, the ability of a country to nurture the growth of such businesses is probably the most important element in enterprise development."

However, it remains an open question whether HGFs make the same scale of contribution to job creation and economic development in all regions and localities. This paper offers a peripheral region perspective on HGFs based on a study of HGFs headquartered in Scotland. . Scotland provides a useful empirical context for this work. First, it has historically encountered low levels of business start-ups compared to other UK regions (Scottish Enterprise, 1993) remaining one of the least entrepreneurial regions of the UK (Van Stel and Storey, 2004). Second, the policy focus of the Scottish Government during the past decade has been on producing more HGFs. The paper therefore has wider relevance beyond Scotland to other peripheral regions and countries with a similar policy 
focus (OECD 2013). However, it has to be acknowledged that the findings may be specific to the unique recessionary conditions that characterised the study period.

\section{LITERATURE REVIEW}

The vast majority of job generation studies have been based on the aggregate analysis of business databases (Henrekson and Johansson, 2010). These have a number of limitations. It is often unclear what is the unit of analysis. Specifically, is it firms or establishments? Are subsidiary companies that have their own separate legal identity included? Nor is it always apparent whether the employment in multi-site enterprises is allocated across all locations or attributed to the head office site. Neither is it always transparent the extent to which the growth of HGFs is attributable to acquisition or organic growth (Henrekson and Johansson, 2010; McKelvie and Wiklund, 2010). Some observers claim the job creation attributed to HGFs may be exaggerated because employment in acquired firms shows up as 'new' jobs. The range of information on each business is typically restricted to size and sector. The consequence of this methodological bias towards quantitative studies is that "key characteristics of HGFs remain unknown" (Coad et al, 2014, p. 106) . This has led to calls for more in-depth qualitative analysis in the field of high growth entrepreneurship (Anyadike-Danes et al, 2013; Brown et al, 2014).

Age - the importance of 'gazelles'

The key role of small firms in job creation was originally identified in the job generation studies of the 1970s in the USA (Birch, 1979; 1981; Armington and Odle, 1981). This conclusion was quickly qualified by Birch (1987) and others (e.g. Harrison, 1994; Kirchhoff, 1994; Kirchhoff and Greene, 1998; Storey, 1994) who emphasised that the main contribution to job creation comes from a small number of young, fast growing firms, which Birch (1981) christened 'gazelles'. Subsequent research has debated the definition of HGFs (OECD, 2008), noting that there is limited overlap between firms defined by different measures of growth (employment, turnover) (Delmar et al, 2003), or between growth and profits (Markman and Gartner, 2002; Davidsson et al, 2009). Based on a review of some 
20 aggregate studies, Henrekson and Johansson (2010) found that a few rapidly growing firms generate a large share of net new jobs and that such firms are relatively younger on average. Both small and large firms are net job creators, although large firms are more important in absolute terms. They also found that HGFs exist in all industries and, significantly, are not over-represented in hightechnology industries (Vanacker and Manigart, 2010). Arrighetti and Lasagni (2013) also report that HGFs are younger than the average firm. However, studies by Acs et al (2008) and Anyadike-Danes et al $(2009 ; 2013)$ have challenged the view that young firms dominate the job creation process, reporting that in their studies in the USA and UK respectively, older, established businesses are the major source of job creation.

\section{Nature of growth}

Not only do very few firms achieve significant growth, for those which do, growth is typically highly discontinuous (Garnsey et al, 2006; Parsley and Halabishy, 2008; Holzl, 2014). This has the implication that a firm which meets the definition of high growth in the period $t_{1} t_{0} t_{2}$ is unlikely to qualify as a high growth firm in the period $t_{2}$ to $t_{3}$, but could reappear in the period $t_{n} t_{n+1}$. This has also prompted scholars to question the relevance of staged growth models (Levie and Lichtenstein, 2010). Indeed, the heterogeneous nature and vagaries of firm growth is increasingly encouraging the view that it is something of a 'random walk' (Coad et al, 2014). An emerging line of enquiry conceptualises the notion of key 'growth triggers' as a fundamental determinant of firm growth (Brown and Mawson, 2013). Understanding why (and how) some firms are able to capitalise on these growth opportunities or overcome these 'growth triggers', or 'critical junctures' (Vohora et al, 2004), is central to our understanding of HGFs (Brown and Mawson, 2013).

\section{Drivers of high growth}

Turning to the causes of rapid firm growth, several factors have been explored but few show direct causality (Coad, 2009). The link between high growth and innovation has been explored in several studies. While far from clear-cut (Freel and Robson, 2004), the majority of studies report a positive relationship between firm-level innovation and high growth (Coad, 2009; Mason et al, 2013). 
However, Hinton and Hamilton (2013) in their study of HGFs in New Zealand offer a more nuanced view of the link between innovation and growth. They report that while all of their HGFs viewed their product, service or value proposition as innovative, in all cases the innovation stopped short of true novelty and was, instead, an alternative marketing or distribution strategy or an amendment to an existing service value proposition (and hence did not require significant $R \& D$ expenditure). In other words, the focus of HGFs is more likely to be on what some have termed "mid-level innovation" (Bhidé, 2008) and others "minnovation - that unexpected twist on an existing idea" (Isenberg, 2013: $11)$.

\section{Growth strategies}

It is also argued that HGFs follow a distinctive business strategy, seeking market niches with little in the way of effective competition (Hinton and Hamilton, 2013). This is achieved in three ways: first, by favouring business rather than consumer markets; second by developing close relationships with a small number of large customers; and third, by emphasizing customer service as a key basis of differentiation in the market which, in turn, requires a significant emphasis on staff training. There is evidence that HGFs use innovation to compete on the basis of differentiation, enabling them to be price setters rather than price takers. Collaboration strategies such as joint ventures, consortia and alliances also appear to be critical for such firms, enabling them to access a broader base of resources (Mohr and Garnsey, 2014) consistent with the 'open innovation' model (Chesbrough, 2003). Exporting and early internationalisation are also characteristics of HGFs, particularly for those located in small countries, in order to broaden the customer base and increase sales volume (Brown and Mawson, forthcoming).

\section{The entrepreneur dimension}

Another significant strand in the HGF literature relates to the distinctive characteristics of the founder(s) (Dodds and Hamilton, 2007; Capelleras and Greene, 2008). Four key founder-related variables are associated with high growth (Dodds and Hamilton, 2007): (i) start-up motivation, with the desire to exploit a market opportunity much more important than push-related motives; (ii) 
amount of education and subject along with soft skills such as search, foresight, imagination and communication emerge as important; (iii) experience - the role of prior entrepreneurial experience is a distinct advantage; (iv) size of the management team - with larger teams linked to high growth on account of their greater resources and expertise. In terms of business practices, their motivation was to create unique value for their customers based on their detailed customer knowledge (Barringer et $a l, 2005)$. They are also open to and willing to actively search for relevant advice on an ongoing basis (Barringer et al, 2005; Hinton and Hamilton, 2013). Somewhat paradoxically, however, HGFs make limited use of public sector advice and support (Smallbone et al, 2002), often preferring peer-based advice and support instead (Fischer and Rueber, 2003).

\section{The geography of HGFs}

Audretsch (2012) has commented on the 'paucity' of research that addresses the locational determinants and dynamics of HGFs. The existing literature allows three observations to be made. First, HGFs exhibit a distinctive geography, being disproportionately concentrated in specific regions and localities. Using Government microdata, Acs and Mueller (2008) found that the locational distribution of gazelles in the USA is far from random, with $40 \%$ of gazelles located in just 20 cities. These 'gazelle regions' are primarily large cities on the west coast (e.g. Los Angeles, Seattle, San Francisco, San Diego), around Chicago and on the east coast (e.g. New York, Boston, Washington DC, Miami, Tampa). The employment effect of new firm formation is greatest in these cities. An analysis of the annual INC 500 listing of fastest growing private companies in the USA from 1982 to 2010 by Motoyama and Danley (2010) found that in the 2000s, at the state level, California and Texas had the most HGFs and were also the top states when normalised by population, followed by Virginia, New York and Florida. Moreover, this geographical distribution of HGFs has become more unequal over time. However, neither the availability of venture capital, high tech, university R\&D nor patents per capita were statistically associated with the geography of HGFs.

In the UK, Gallagher and Miller (1991) noted that gazelles are three times more prevalent in the South East of England than in Scotland per head of population. BERR's (2008) analysis of the Fast Track 
tech database found that $57 \%$ of these firms were located in London and the South East, well above these regions' combined economic weight (e.g. $27 \%$ of population, $28 \%$ of employment; $33 \%$ of GVA). In Norway the regional distribution of rapid-growth firms is largely in line with the overall distribution of businesses, although they are under-represented in most peripheral regions. There is greater disparity at the urban scale, with fast growing firms relatively concentrated in medium sized cities (Bastesen and Vatne, 2014). This is attributed, at least in part, to industry factors and specifically to fast growth firms in the energy sector which are located in oil and gas clusters which are found in second tier cities along Norway's west coast.

The second point is that HGFs can be found in all types of location - core regions and peripheral regions, and large city and rural area. In the case of the UK, Vaessen and Keeble (1995) have noted that fast growth firms are located in both peripheral and core regions, indicating that "firms have been able to grow in environments which lack the range and scale of facilities and agglomeration advantages of the South East" ( $\mathrm{p}$ 502). They conclude that firms are able to achieve fast growth in peripheral regions by developing place-specific strategies to overcome the constraints of such locations. This is reflected in differences between fast growth firms in peripheral regions and the South East in terms of the nature of competition, innovation activity and technological intensity and skill structures.

Third, following on from the previous point, there is evidence of qualitative differences in the nature of HGFs in different regions. Gallagher and Miller (1991) reported that gazelles in the South East had a much higher turnover and created twice as many jobs on average as those in Scotland (348 cf. 160), and accounted for a much bigger share of job creation. They also note sectoral differences, with manufacturing firms over-represented in Scotland and financial services firms under-represented compared with South East England. In The Netherlands Stam (2005) found that the gazelles in knowledge-intensive business services have a different geography to gazelles in high technology manufacturing: the former are disproportionately concentrated in highly urbanised regions whereas the latter are concentrated in rural areas. 


\section{Summary}

In summary, research shows HGFs are significant job generators. However, growth is episodic, hence the population of HGFs is constantly changing over time. HGFs are relatively youthful, are innovative but not disproportionately high-tech, and pursue distinctive business strategies. They also have distinctive geographies. Moreover, it has been suggested that HGFs in different regions may have distinctive characteristic and operational styles which raises the possibility that they will have different economic impacts in different regional contexts. More regionally-focused empirical research is therefore required to better understand the regional dynamics of HGFs.

\section{DATA SOURCES}

The research is based on a combination of quantitative and qualitative approaches. The quantitative analysis involved the first-ever regional analysis of the ONS Inter-departmental Business Register (IDBR) of businesses to compare the population of HGFs in Scotland and other UK regional economies (the ONS Business Structure Database). As noted earlier, this data source has been successfully used in other UK studies of HGFs (Anyadike-Danes et al, 2009; 2013; Hart and Anydike-Danes, 2014). The OECD definition was used to define high growth firms: "enterprises with average annualised growth in employees or turnover greater than $20 \%$ per annum, over a three year period, and with more than 10 employees in the beginning of the observation period, should be considered as high growth enterprises" (OECD 2010, p. 16). Despite criticism, it has become the standard analytical approach for measuring these firms (Coad et al, 2014).

The qualitative dimension of the study comprised interviews with senior management in HGFs. The names of individual firms are not available on the IDBR data and so it could not be used as a sampling frame. Instead, as a first step, HGFs in Scotland were identified from the FAME database (published by Bureau Van Dijk) which provides comprehensive information on UK companies based on Companies House filings. FAME is a live database that is being continually updated as companies submit their latest annual accounts to Companies House. At the point in time when the analysis was 
undertaken, 825 HGFs in Scotland were identified as meeting the standard OECD turnover definition of such enterprises. . . The FAME database has two limitations regarding the age of the information. First, although companies are required to submit their accounts within 28 days of the end of their financial year, some are late in filing, despite financial penalties for doing so. For such companies the information on FAME will be out-of-date. Second, because companies have different the financial year-ends the information covers different time-periods. A further limitation relates to FAME's treatment of ownership. It includes UK-registered companies that are owned by foreign companies. Further analysis revealed that of firms where ownership information was provided, only $61 \%$ of HGFs were UK-owned. Moreover, FAME does not differentiate between Scottish-owned firms and UKowned firms. Identifying Scottish owned and headquartered firms required additional desk research.

The HGFs identified from the FAME database constituted the sampling frame for the interviewbased survey. A random sample of 95 HGFs classified as being UK-owned was selected. Detailed desk research on these firms revealed that six had closed and 36 did not meet the study's criteria because they were either subsidiaries or divisions or their head office was not in Scotland. Indeed, twelve had recently been acquired by non-Scottish companies. This left a valid sample of 53 firms. Indepth interviews (mostly face-to-face) were undertaken with a member of the senior management team (typically the CEO) of 22 of these firms, a 41 per cent response rate. The main reason for the attrition in numbers was difficulties in contacting CEOs to arrange interviews. There were only four refusals. Comparing the characteristics of the interviewee firms with the larger sample of FAME firms suggests that the sample were representative of Scottish HGFs in terms of their age, size and sectoral composition and geographical distribution.

The interviews form the core of the empirical material in this paper. However, recognising that reality is often constructed differently by various agents and groups (Glaser and Strauss, 1967), where possible interviews were also conducted with business development officers from Scottish Enterprise who engaged with many of the case study firms to provide a complementary perspective to that provided by the firms. Finally, as others have done (e.g. Fischer and Reuber, 2003), three workshops 
and several informal meetings were held with policy makers and business development officers to 'road test' and triangulate some of the study's emerging findings, interpretations and policy implications.

\section{THE SIGNIFICANCE OF HIGH GROWTH FIRMS IN SCOTLAND}

The analysis of Scottish HGFs on the ONS database covered the period between 2007 and 2010 when the UK economy moved into recession. To be included in the population (i.e. the denominator of the HGF calculation) firms needed to satisfy three conditions: be born before 2007; be alive in 2010; and have 10 or more employees in 2007 . This analysis indicates that there are regional differences in the significance and impact of HGFs. In the period studied Scotland outperformed much of the UK in terms of the percentage of businesses that are HGFs. Using the OECD's turnover definition of high growth, there were 1,544 HGFs in Scotland in 2010 comprising $13.5 \%$ all firms with $10+$ employees. This figure is above the UK average (12.9\%). Indeed, during this period Scotland was second only to Greater London and higher than all other UK regions (Figure 1). However, the effect of its low business birth rate on the stock of businesses may play some role in this (Van Stel and Storey, 2004).

\section{FIGURE 1 ABOUT HERE}

Using an employment definition of high growth to be consistent with the previous work of AnyadikeDanes et al (2009), between 2007 and 2010, 7\% of Scotland's businesses with 10+ employees were HGFs . This is slightly above the UK average (6.9\%). Less satisfactory for Scotland is that its HGFs are less significant generators of employment than their counterparts in the rest of the UK. They increased their employment by $23 \%$ (or 54,188 jobs) over the 2007-2010 period. The equivalent percentage increase for the UK was 39.5\%. Scottish HGFs are well established, with just over half (53\%) being in existence for 10 years or more, compared with $44 \%$ for the UK as a whole. This contradicts the majority of studies which portray HGFs as youthful (Henrekson and Johansson, 2010). But consistent with the literature, HGFs are found in all the main sectors of the Scottish economy and are not over-concentrated in technology sectors. Just $18.4 \%$ of Scotland's high technology firms were 
HGFs, in line with the UK average but only $12.2 \%$ of its HGFs were in high technology sectors, a lower proportion than in most other regions.

\section{EXPLORING THE CHARACTERISTICS OF SCOTTISH HIGH GROWTH FIRMS}

Age, Size and Antecedents

The characteristics of the 22 firms interviewed confirms the heterogeneity of HGFs. First, in terms of their age profile, only five firms were less than 10 years old. Half were founded in the $1970 \mathrm{~s}(n=4)$, 1980s $(n=3)$ or 1990s $(n=5)$. At the other extreme, two firms were founded before World War One. This provides yet further confirmation that fast growing firms are not confined to recent starts and that genuine 'gazelles' - HGFs less than five years of age (OECD, 2008) - represent a tiny minority of HGFs. Second, the ownership structure is highly varied. Six were family businesses and one was an employee-owned business. Amongst the remainder, five were publicly listed (three on the Main Market and two on the Alternative Investment Market (AIM)) and four had a majority external shareholder (two of which were private equity firms). Third, the existing literature implies that fast growth firms are predominantly de novo starts which conform to the entrepreneurial model of a business that is started from scratch by an entrepreneur, or entrepreneurial team. At best, only nine firms $(41 \%)$ could be described as conforming to this description - and in five of these cases the founding entrepreneur is no longer running the company. Instead, the majority of firms had been 'preincubated' - in the sense of previously being part of other organisations. In all cases rapid growth only occurred after these businesses had become independent. This has taken various forms. The single biggest category amongst the firms interviewed were management buyouts (MBOs) and buyins (MBIs) $(\mathrm{n}=8)$. This was also evident in the wider FAME sample of 53 firms that were examined using secondary research. The other cases comprise an employee-buyout of the commercial interests of a not-for-profit organization, a free-standing business established in a new industry by longestablished family owned company, and three long-established businesses that have been reinvigorated under new management. This 'pre-incubation' process is a significant feature of HGFs that has not been identified in the literature. Moreover, it supports, reinforces and extends earlier 
work, also undertaken in Scotland, which observed that established business groups are another 'preincubated' source of successful new firms (Rosa, 1998; Rosa and Scott, 1999a; 1999b).

Another feature of the sample is the prevalence of serial entrepreneurship. Five entrepreneurs - four involved in de novo starts and one in a MBO-based start-up - were serial entrepreneurs with prior entrepreneurial experience. In two cases the entrepreneurs had been successful, selling their previous businesses and reinvesting their financial wealth and experience to start a new business in the same industry. In two further cases, which illustrate Ronstadt's 'corridor principle' (Ronstadt, 1988), the entrepreneurs were running other businesses when they identified new opportunities in unrelated areas. In the final case the new business was 'pre-incubated' within the entrepreneur's existing business, with the existing business providing the resources needed to develop the product that formed the basis of the new business.

Two insights can be drawn from this evidence. First, HGFs are not restricted to de novo start-ups. They are often incubated in one form or another in existing businesses, often for a considerable amount of time, to emerge as fully-formed businesses. It may be that this pre-incubation feature is more evident in peripheral regions because of their lower business start-up rates. Second, there is a need to separate the 'entrepreneur' from the 'business'. In the majority of cases the success of HGFs was attributable not to their founding entrepreneurs but to professional CEOs who had taken control at various points post-start-up.

\section{Growth Processes}

As noted earlier, even amongst HGFs the pattern of growth rarely conforms to the classic 'reverse hockey stick' in which revenue starts growing at a normal linear pace and then, once an inflection point is hit, growth takes off at an exponential rate. In reality, growth is usually episodic and growth setbacks are common in HGFs (Garnsey et al, 2006; ). This is also reflected here, with just five interviewees describing the growth of their firm as taking a reverse hockey stick pattern. Nine interviewees described their growth as being 'incremental'. 
In the majority of companies (15) companies had grown exclusively through organic expansion. Five companies had grown primarily through acquisition, either to access complementary products and services or gain market presence. For these firms - which comprise the larger firms in the sample acquisition has become an increasingly important growth strategy over time and is often a key component of their internationalization. In the remaining cases, growth had been through a combination of organic expansion and some smaller scale acquisitions.

\section{Industries, Markets and Customers}

As already emphasized, HGFs are not concentrated in a small group of industries. This is reflected in the activities of the HGFs that were interviewed. But what was particularly striking is where fast growth firms were scarce or absent. The vast majority of the firms interviewed (18 of the 22) were engaged in selling to other businesses (B2B). Only three firms sell directly to the general public. And few firms were engaged in manufacturing. Only one firm was exclusively engaged in manufacturing, while three other firms described themselves as total systems providers, engaged in manufacturing along with design and customer support. Three other product based firms outsourced most or all of their manufacturing and focused on design, installation, maintenance and support. Indeed, it was apparent that the vast majority of the manufacturing firms had a significant service component as part of their offering, underlining the pivotal position that service activities now assume in the production process. As Bryson et al (2002, p. 978) have noted, the "profitability [of manufacturing firms] increasingly depends not just on the manufacturing part of the production process, but on the knowledge aspects and service functions within which the products are embedded."

Third, few HGFs are in technology sectors, with just four companies in our sample (18\%) classified as such. This feature is confirmed in the wider FAME sample where less than $20 \%$ of Scottish-owned firms were in high technology sectors. That said, several companies could be classified as knowledgebased, having developed innovative products and services. Moreover, all four manufacturing firms were continually developing innovative products, and the other product-based firms were selling their 
knowledge as part of their overall business package. Several had developed innovative business models (Teece, 2010). In many cases the business models took the form of a 'recurring revenue' model (Osterwalder and Pigneur, 2010). Several other firms have a business model based around technical advice, design, supply/ installation, business support (including training services) and maintenance contracts which includes a significant component of recurring income. Overall, around two-thirds of the sample could be described as being innovative - opening new markets, bringing new products and services to market, or developing new business models. In other words, it was this innovative end-user-orientation, rather than technological innovation per se, which was the key driver for propelling firms towards rapid growth. This strong B2B orientation and use of business models that target 'solutions' has meant that many of the firms derive their sales from ongoing relationships with existing customers rather than from one-off transactional relationships. Close relationships with customers gives firms a deep knowledge of their markets (Von Hippel, 2009), providing them with an understanding of their customers' needs and wants, and the ability to anticipate their future need. This approach was described by one company in the oil and gas industry as "mine-sweeping" their customer's ideas.

\section{Financing Growth}

The ability to raise equity finance is often seen as critical to enable rapid expansion (Lerner, 2010). Eleven firms - half of the firms in our sample - had raised venture capital, in nine cases from venture capital funds and in two cases from corporate investors. This is a much higher proportion than reported in other studies (e.g. Vanacker and Manigart, 2010; Brown and Lee, 2014). In four cases the investment funded the $\mathrm{MBO} / \mathrm{MBI}$. In the other seven cases the start-up was self-funded with venture capital raised to finance expansion. In one of these cases, business angels played a particularly important role in funding the company all the way from start-up to Initial Public Offering (IPO), with Venture Capitalists (VCs) only investing a couple of years prior to the IPO. As noted earlier, five of these companies are now listed on the London Stock Market. 
Seven firms - one-third of the sample - have been internally financed. These include the long established family firms. Their self-funding approach largely reflected the strong desire of the owners to retain their independence. It is interesting to note that this group includes three of the five firms that were awarded Regional Selective Assistance (RSA) grants whereas only one VC-backed firm had been awarded RSA. ${ }^{1}$ This prompts the speculation, consistent with the 'pecking order' hypothesis of financing preferences (Myers and Majluf, 1984), that public sector grants may, in some cases, be substituting for external funding sources in situations where the owner-managers deliberately forego external finance to retain independence of ownership and self-autonomy. Two firms were initially self-funded by their founding teams from the wealth that they had created by selling their previous businesses, illustrating the process of 'entrepreneurial recycling' (Mason and Harrison, 2006) which can occur following the sale of an entrepreneur's previous business.

\section{Embeddedness}

With just one exception, the businesses that were interviewed are located in Scotland because that is where the founders were living and working at the time that the company was started, confirming that entrepreneurship is very much a 'local' event (Dahl and Sorenson, 2011). Eleven CEOs commented that they "could be based anywhere" but remained in Scotland because that is where they wanted to live. The absence of non-Scots business founders is also striking in view of emerging evidence on links between in-migration and entrepreneurship (Levie, 2007). This too, may be a distinctive feature of HGFs in peripheral regions such as Scotland which typically lack the types of high level job opportunities that would attract talented workers from other regions and countries (Houston et al, 2008). Indeed, the flow of talent from peripheral regions such as Scotland is typically to London (Findlay et al, 2008; Champion, 2012). The implication is that the emergence of HGFs in peripheral economies is largely a function of the supply of entrepreneurs in the region, with the existing structure of industry and employment of a region being a major determinant of the pool of potential founders and senior management of HGFs.

\footnotetext{
${ }^{1}$ Regional Selective Assistance (RSA) is a discretionary grant providing assistance towards projects with fixed capital expenditure that will create or safeguard employment in certain eligible geographic areas in the UK.
} 
However, the home location becomes a 'stickier' place (Markusen, 1996) over time as companies grow, particularly through their labour market ties, spillovers from key industrial clusters - especially in the case of oil and gas companies - and in some cases relationships with their banks, professional advisers and public agencies. For some firms a Scottish location was also seen as an asset, especially those selling into the USA which all identified the benefits that 'brand Scotland' provided. Three respondents - a financial services company in Edinburgh and two oil and gas related companies in Aberdeen - emphasized that the 'place' brand in their respective sectors was more important than 'brand Scotland'. Hence, for all these reasons most entrepreneurs perceived that relocation from Scotland was neither feasible nor desirable.

\section{Internationalisation}

The majority of the HGFs interviewed are oriented to UK and global markets and most have a physical presence beyond Scotland. Only five companies, including two Aberdeen-based companies in the oil and gas sector, actually undertake the majority or all of their business in Scotland. At the other extreme, 14 companies derived the majority (over 75\%) of their sales outside of Scotland. This orientation towards non-Scottish markets is reflected in the corporate geographies of the interviewed companies. Ten had a physical presence - often a significant one - elsewhere in the UK and in foreign markets (mainly US and Dubai), typically for sales and field support, and four have locations across the UK, again mainly for customer support. Some of the publicly listed companies have started to make small strategic acquisitions of companies in other countries to access complementary products and services.

The consequence is that the direct Scottish 'footprint' of many HGFs is quite small, often limited to headquarters functions, with the majority of the jobs located elsewhere in the UK and abroad. Indeed, half of the 22 firms that were interviewed employed more people outside of Scotland than they did in Scotland. This reflects a combination of the service-oriented nature of the majority of the businesses, which requires a physical presence close to customers, and the need for sales and support staff in 
export markets. For such companies it is almost inevitable that further growth involving the penetration of new geographical markets, especially if it is achieved through acquisitions, will reduce their Scottish footprint, at least in relative terms. It might therefore be the case that fast growth businesses in small, geographically peripheral economies such as Scotland have a smaller direct local economic impact than their counterparts in core regions. This is consistent with the aggregate evidence on the smaller size and lower rate of job growth of Scottish HGFs reviewed earlier.

Nevertheless, it is important to emphasise the economic importance of the head office. First, they create high quality managerial jobs. Second, because of the nature of these jobs head office staff may leave to start their own businesses using the knowledge and experience that they have gained. Third, purchasing decisions made at head office may favour local suppliers, thereby creating additional indirect jobs through the supply chain. However, head offices are vulnerable in the event of ownership change. In the three years since the interviews five of the 22 interviewed firms have been acquired. Companies that have raised finance from private equity funds, either to grow the business or to finance a management buyout, are particularly vulnerable to being acquired because of the 'exit' orientation and short-term investment horizon of such investors. The immediate and longer term implications of being acquired are not clear and need to be a priority for future research. However, the CEO of a company whose Scottish presence is limited to a head office acknowledged that he was 'certain' that if they were acquired: "the first thing an acquirer would do is to close this building down. They would not need it." But he added that this would prompt senior management to leave and start-up their own companies. Change of ownership of a business can therefore be an important stimulus to business start-up by its former owners and managers. Three of the companies interviewed were started by people who had left their previous employment because of their dissatisfaction following the company's takeover. .

\section{CONCLUSION AND POLICY IMPLICATIONS}

Growing evidence of the significant contributions of HGFs to job creation and economic development has resulted in them becoming the policy focus for an increasing number of regional and national 
governments and international organisations (Bleda et al, 2013; OECD, 2013; Brown et al, 2014). However, the underlying empirical evidence underpinning this policy focus lacks an explicit geographical focus. It therefore remains unclear the extent to which geographical context influences the emergence, characteristics and economic impact of HGFs. This paper has sought to address this and other deficiencies in the literature by means of an in-depth study of HGFs in Scotland. It makes four main contributions to the evolving academic literature on high growth entrepreneurship.

First, the aggregate analysis indicates that location is not a barrier to business growth. Nevertheless, Scottish HGFs are smaller than their counterparts in the rest of the UK and do not appear to create as much local employment. This suggests that from a peripheral region perspective HGFs may not be the policy panacea that has been claimed and raises questions about the utility of a 'one-size-fits-all' policy approach towards their support.

Second, the qualitative research has revealed that Scottish HGFs have a significant overseas presence, with the consequence that much of their job creation does not occur locally, thereby reducing their domestic 'footprint'. This reflects both the smaller populations and economies of peripheral regions and the high service content of their activities.

Third, the study has highlighted the varied origins and complex growth dynamics of HGFs, features that are often overlooked in the high growth literature. The majority are not high-tech firms despite the fact that many entrepreneurship policies strongly focus upon these types of firms (Brown and Mason, 2014; Vanacker, T., Manigart, 2010). Policy should therefore be 'sector agnostic' and aim to stimulate and support HGFs irrespective of sector. Moreover, many HGFs are not the de novo startups depicted in the literature. In reality, many are established firms which have undergone MBOs, MBIs or employee buy-outs. The significance of MBOs and MBIs in particular has not been identified in previous studies. This is something that policy makers should consider when designing policy initiatives. 
Fourth, the research has highlighted the high level of acquisition of HGFs. The acquisition of HGFs is an issue that affects the UK as a whole (House of Commons, 2011; Mohr and Garnsey, 2011).

However, it may be of greater significance in peripheral regions on account of the smaller number of growth-oriented firms in such locations. Scottish HGFs appear to be particularly vulnerable to acquisition as a consequence of their high level of investment from venture capital and private equity firms. These investors need to achieve exits, typically through the sale of their investee companies. One recent study suggests that acquisition is harmful to the subsequent growth of acquired firms, especially for those in their early stage of development (Xioa, 2013). The potential adverse effects of acquisition need to be explored. Policy makers in peripheral regions should therefore consider how to prevent or mitigate the negative effects of this process (Hinton and Hamilton, 2013).

Finally, from a policy perspective the paper suggests that the tendency towards 'policy universalism' in the sphere of entrepreneurship and innovation policy is problematic (Gertler, 2010; Welter, 2011). An appropriate policy focus at the level of the nation-state may not be appropriate for its constituent regions, especially in a diverse national economy such as the UK. In turn, this suggests the need for entrepreneurship policies to be better attuned to local economic specificities. If all regions are to benefit equally from the fragile economic recovery taking places within the UK economy, enterprise policies need to be based on a proper understanding of the complex determinants of firm growth within different regional environments.

ACKNOWLEDGEMENT. This paper is based on research that was undertaken on behalf of Scottish Enterprise. The statistical data used here is from the Office of National Statistics (ONS) and is Crown copyright and reproduced with the permission of the controller of HMSO and Queens Printer for Scotland. The use of the ONS statistical data in this work does not imply the endorsement of the ONS in relation to the interpretation or analysis of the statistical data. The analysis upon which this report is based uses research datasets which may not exactly reproduce National Statistics aggregates.

\section{REFERENCES}

Acs, Z. and Mueller, P. (2008) Employment effects of business dynamics: Mice, Gazelles and Elephants, Small Business Economics, 30, 85-100. 
Acs, Z., Parsons, W. and Tracy, S. (2008). High-Impact Firms: Gazelles Revisited. Washington: United States Small Business Administration. Download from: http://archive.sba.gov/advo/research/rs328tot.pdf

Anyadike-Danes, M., Bonner, K., Hart, M. and Mason, C. (2009) Measuring Business Growth: High Growth Firms and their Contribution to Employment in the UK, Research Report MBG/35, London: National Endowment for Science Technology and Arts (NESTA).

Anyadike-Danes, M., Bonner, K. and Hart, M. (2013) Exploring the Incidence and Spatial Distribution of High Growth Firms in the UK and their Contribution to Job Creation, NESTA Working Paper 13/05, London: National Endowment for Science Technology and Arts (NESTA). Download from:

http://www.nesta.org.uk/library/documents/exploringtheincidenceandspatialdistribution.pdf

Armington, C. And Ogle, M. (1982) Small Business - How Many Jobs?, The Brookings Review, Winter, 14-17.

Arrighetti, A and Lasagni, A (2013) Assessing the determinants of high-growth manufacturing firms in Italy, International Journal of the Economics of Business, 20 (2), 245-267.

Audretsch, D. (2012) The Determinants of High Growth Entrepreneurship, paper presented at the OECD/DBA International Workshop on 'High growth firms: local policies and local determinants' Copenhagen, 28 March, 2012. Download from: http://www.oecd.org/cfe/leed/Audretsch determinants\%20of\%20high-growth\%20firms.pdf

Barringer, B.R., Jones, F., and Neubaum, D.O. (2005) A quantitative content analysis of the characteristics of rapid-growth firms and their founders, Journal of Business Venturing, 20, 663-687.

Bastesen, J and Vatne, E (2014) The geography of rapid-growth firms: exploring the role and location of entrepreneurial ventures. In C Karlsson, B Johansson and R R Stough (eds.) Agglomeration, Clusters and Entrepreneurship: Studies in Regional Economic Development. Cheltenham: Edward Elgar, pp159-198. 
BERR (2008) High Growth firms in the UK: Lessons from an analysis of comparative UK performance. BERR Economics Paper No.3, London: Department for Business Enterprise \& Regulatory Reform. Download from: http://www.berr.gov.uk/files/file49042.pdf

Bhidé, A (2008) The Venturesome Economy, Princeton University Press: Princeton.

Birch, D. (1979) The Job Generation Process, MIT Program on Neighbourhood and Regional Change, Cambridge.

Birch, D. (1981) Who creates jobs? Public Interest, 65, 3-14.

Birch, D. (1987) Job Generation in America, New York, The Free Press.

Bleda, M., Morrison, K. and Rigby, J. (2013) The Role and Importance of Gazelles and Other Growth Firms for Innovation and Competitiveness, in Cox, D. and Rigby, J. (Eds) Innovation Policy Challenges for the 21st Century, pp. 36-63, Routledge, London.

Brown, R and Lee, N (2014) Funding Issues Confronting High Growth SMEs in the UK, Edinburgh: ICAS. http://icas.org.uk/brown-lee/

Brown, R and Mason, C (2014) Inside the high-tech black box: a critique of technology entrepreneurship policy, Technovation, 34, 773-784. .

Brown, R. and Mawson, S. (2013) Trigger Points and High Growth Firms: A Conceptualisation and Review of Public Policy Implications. Journal of Small Business and Enterprise Development, 20 (2), 279-295.

Brown, R. and Mawson, S. The geography of job creation in high growth firms: the implications of 'growing abroad', Environment and Planning C: Government and Policy, forthcoming.

Bryson, J R, Daniels, P W and Warf, B (2002) Service Worlds: People, Organisations and Technology. London: Routledge.

Capelleras, J-L. And Greene, F.J. (2008) The determinants and growth implications of venture creation speed, Entrepreneurship and Regional Development, 20, 317-343.

Centre for Cities (2014) Cities Outlook 2014, http://www.centreforcities.org/research/outlook14.html Champion, T (2012) Testing the return migration element of the 'escalator region' model: an analysis of migration into and out of south-east England, 1966-2001, Cambridge Journal of Regions Economy and Society, 5 (2): 255-270 
Champion T, Townsend A, (2013) Great Britain's second-order city regions in recessions, Environment and Planning A, 45(2) $362-382$

Chesborough, H. W. (2003) Open Innovation: The New Imperative for Creating and Profiting from Technology, Boston, Harvard Press.

Coad, A. (2009) The Growth of Firms, Edward Elgar Publishing Limited, Cheltenham.

Coad, A. Daunfeldt, S-O Hözl,, W. Johansson, D and Nightingale, P. (2014) High-growth firms: introduction to the special issue, Industrial and Corporate Change, 23, 91-112.

Dahl, M. and Sorenson, O. (2009) The Embedded Entrepreneur, European Management Review, 6, $172-181$.

Davidsson, P., Steffens, P. and Fitzsimmons, J. (2009) Growing profitable or growing from profits: putting the horse before the cart?, Journal of Business Venturing, 24, 388-406.

Delmar, F., Davidsson, P. and Gartner, W. B. (2003) Arriving at the high-growth firm, Journal of Business Venturing, 18, 189-216.

Dodds, M. and Hamilton, R. T. (2007) Small business growth: recent evidence and new directions, International Journal of Entrepreneurial Behaviour and Research, 12, 291-309.

Du, J., Gong, Y. and Temouri, Y. (2013) High Growth Firms and Productivity: Evidence from the $U K$, NESTA, London [http://www.nesta.org.uk/publications/working_papers/assets/features/high_growth_ firms_and_productivity]

Feldman, M. A., Francis, J. and Bercovitz, J. (2005) Creating a Cluster While Building a firm: Entrepreneurs and the Formation of Industrial Clusters, Regional Studies, 39, 129-141.

Fischer, E. and Reuber, A. (2003) Support for Rapid-Growth Firms: A Comparison of the Views of Founders, Government Policymakers, and Private Sector Resource Providers, Journal of Small Business Management, 41, 346-365.

Freel, M. and Robson, P. (2004) Small firm innovation, growth and performance, International Small Business Journal, 22, 561-575. 
Gallagher, CC and Miller, P.(1993) The performance of new firms in Scotland and the South East, 1980-87, The Royal Bank of Scotland Review, 170, 96- 101

Garnsey, E., Stam, E. and Heffernan, P. (2006) New firm growth: Exploring processes and paths. Industry and Innovation, 13, 1-20.

Gertler, M. (2010) Rules of the Game: The Place of Institutions in Regional Economic Change, Regional Studies, 44, 1-15.

Glaser, B. and Strauss, A. (1967) The Discovery of Grounded Theory: Strategies for Qualitative Research. New York, Aldine.

Harrison, B. (1994) The small firm myth, California Management Review, 36, 142-158.

Hart, M. and Anyadike-Danes, M. (2014) Moving on from the Vital 6\%, Enterprise Research Centre, ERC Insight, February 2014. Download from: http://enterpriseresearch.ac.uk/wpcontent/uploads/2014/02/ERC-Insight-No_3.pdf

Henrekson, M. and Johansson, D. (2010) Gazelles as job creators: a survey and interpretation of the evidence, Small Business Economics, 35, 227-244.

Hinton, M. and Hamilton, R.T. (2013) Characterizing high-growth firms in New Zealand. International Journal of Entrepreneurship and Innovation, 14(1): 39-48.

Hözl, W (2014) Persistence, survival and growth: a closer look at 20 years of fast growing firms in Austria, Industry and Corporate Change, 23 (1), 199-231.

House of Commons (2013) Bridging the valley of death: Improving the commercialisation of research, Science and Technology Committee, House of Commons, London. [http://www.publications.parliament.uk/pa/cm201213/cmselect/cmsctech/

Houston, D, Findlay, A, Harrison, R and Mason, C (2008) 'Will attracting the 'creative class' boost economic growth in old industrial regions: a case study of Scotland?' Geografiska Annaller: Series B. Human Geography, 90, 133-149.

Hutton, W. and Lee, N. (2012) The City and the cities: ownership, finance and the geography of recovery, Cambridge Journal of the Regions, Economy and Society, 5, 325-337. 
Isenberg, D (2013) Worthless, Impossible and Stupid: How Contrarian Entrepreneurs Create and Capture Extraordinary Value, Harvard Business School Press, Boston: Mass

Kirchhoff, B. A. (1994) Entrepreneurship and Dynamic Capitalism, Wesport, Praeger.

Kirchhoff, B. A. and Greene, P. (1998) Understanding the Theoretical and Empirical Content of Critiques of U.S. Job Creation Research, Small Business Economics, 10, 153-169.

Levie, J (2007) Immigration, in-migration, ethnicity and entrepreneurship, Small Business Economics, 28, 143-169.

Levie, J. and Lichtenstein, B. (2010) A terminal assessment of stages theory: introducing a dynamic states approach to entrepreneurship, Entrepreneurship Theory and Practice, 34, 317-350.

Markham, G.D. and Gartner, W.B. (2002) Is extraordinary growth profitable? A Study of Inc 500 high-growth companies, Entrepreneurship and Regional Development, 27, 65-75.

Markusen, A (1996), Sticky Places in Slippery Space: A Typology of Industrial Districts, Economic Geography, 72, (3), 293-313.

Mason, C. and Brown, R. (2013) Creating good public policy to support high growth firms. Small Business Economics, 40, 211-225.

Mason, C. and Harrison, R. (2006) After the Exit: Acquisitions, entrepreneurial re-cycling and regional economic development, Regional Studies, 40, 55-73.

Mason, G., Robinson, C. and Bondibene, C.R. (2012) Fast-growing firms, product strategies and skills development, NESTA Working Paper 12/12, London, National Endowment for Science Technology and Arts (NESTA).

McKelvie, A. and Wiklund, J. (2010) Advancing Firm Growth Research: A Focus on Growth Mode Instead of Growth Rate, Entrepreneurship Theory and Practice, 34, pp. 261-288.

Miles, N. and Huberman, A. (1994) Qualitative Data Analysis: A Sourcebook of New Methods, $2^{\text {nd }}$ Edition, London, Sage.

Mohr, V. and Garnsey, E. (2011) How Do High-Growth Firms Grow? Evidence from Cambridge, UK, Economics, Management and Financial Markets, 4, 29-59.

Mohr, V. and Garnsey, E. (2014) The Role of Alliances in the early development of high-growth firms, Industrial and Corporate Change, 23, 233-259. 
Motoyama, Y and Danley, B (2012) The Ascent Of America's High-Growth Companies: An analysis of the geography of entrepreneurship. Kauffman Research Paper Series. Kansas City, Mo: Kauffman Foundation

Myers, S and Majluf, N. (1984) Corporate financing and investment decisions when firms have information that investors do not have, Journal of Financial Economics, 13, 187-221

OECD (2008) Measuring Entrepreneurship: A Digest of Indicators, OECD-Eurostat Entrepreneurship Indicators Program, Paris, Organisation for Economic Cooperation and Development (OECD). OECD (2010) High-growth enterprises: What governments can do to make a difference, OECD studies on SMEs and entrepreneurship, Paris, Organisation for Economic Cooperation and Development (OECD).

OECD (2011) Financing High-Growth Firms: The Role of Angel Investors, Paris, Organisation for Economic Cooperation and Development (OECD).

OECD (2013) An International Benchmarking Analysis of Public Programmes for High Growth Firms, Paris, Organisation for Economic Cooperation and Development (OECD).

Osterwalder, A and Pigneur, Y (2010) Business Model Generation, Hoboken, NJ: John Wiley and Sons Inc.

Parsley, C. and Halabisky, D. (2008) Profile of Growth Firms: a summary of Industry Canada Research, Ottawa, Industry, Canada.

Rosa, P. (1998) Entrepreneurial processes of business cluster formation and growth by 'habitual entrepreneurs, Entrepreneurship Theory and Practice, 22, 43-62.

Rosa, P. and Scott, M. (1999a) Entrepreneurial diversification, business cluster formation, and growth, Environment and Planning C, 17, 527-548.

Rosa, P. and Scott, M. (1999b) The prevalence of multiple owners and directors in the SME sector: implications for our understanding of start-up and growth, Entrepreneurship and Regional Development, 11, 21-38.

Scottish Enterprise (1993) Improving the Business Birth Rate: A Strategy for Scotland, Glasgow, Scottish Enterprise.

Shane, S (2008) The Illusions of Entrepreneurship. New Haven: Yale University Press 
Shane, S. (2009) Why encouraging more people to become entrepreneurs is bad public policy, Small Business Economics, 33, 141-149.

Smallbone, D., Baldock, R. and Burgess, S. (2002) Targeted support for high-growth start-ups: some policy issues, Environment and Planning C: Government and Policy, 20, 195-209.

Stam, E. (2005) The Geography of Gazelles in the Netherlands, Tijdschrift voor economische en sociale geografie, 96 (1), 121-127.

Storey, D. J. (1994) Understanding the Small Business Sector, Routledge, London.

Storey, D. J. and Greene, F. (2010) Small Business and Entrepreneurship, Harlow, Prentice Hall.

Teece, D. (2010) Business Models, Business Strategy and Innovation, Long Range Planning, 43, 172194.

Townsend, A and Champion T (2014) The impact of recession on city regions: The British experience, 2008-2013, Local Economy, 29 (1-2) 38-51.

Vaessen, P and Keeble, D (1995) Growth-oriented SMEs in unfavourable regional environments, Regional Studies 29, 489-505.

Van Stel, A. J. and Storey, D. J. (2004) The Link Between Firm Births and Job Creation: Is there a Upas Tree Effect?, Regional Studies, 38, 893-909.

Vanacker, T., Manigart, S. (2010) Pecking order and debt capacity considerations for high growth companies seeking finance, Small Business Economics, 35, 53-69.

Vohora, A., Wright, M. and Lockett, A. (2004) Critical junctures in the development of university high-tech spinout companies, Research Policy, 33, 147-175.

Von Hippel, E. (2009) Democratizing Innovation: The Evolving Phenomenon of User Innovation, International Journal of Innovation Science, 1, 29-40.

Welter, F. (2011) Contextualizing entrepreneurship - conceptual challenges and ways forward, Entrepreneurship Theory and Practice, 35, 165-184.Xioa, J (2013) Acquisition and firm growth: the perspective of acquired entrepreneurial firms, paper presented to the Druid Academy. 
Figure 1: High-Growth Firms in the UK Regions 2007-10 (OECD Turnover Definition): as a proportion of All Firms 10+ Employees.

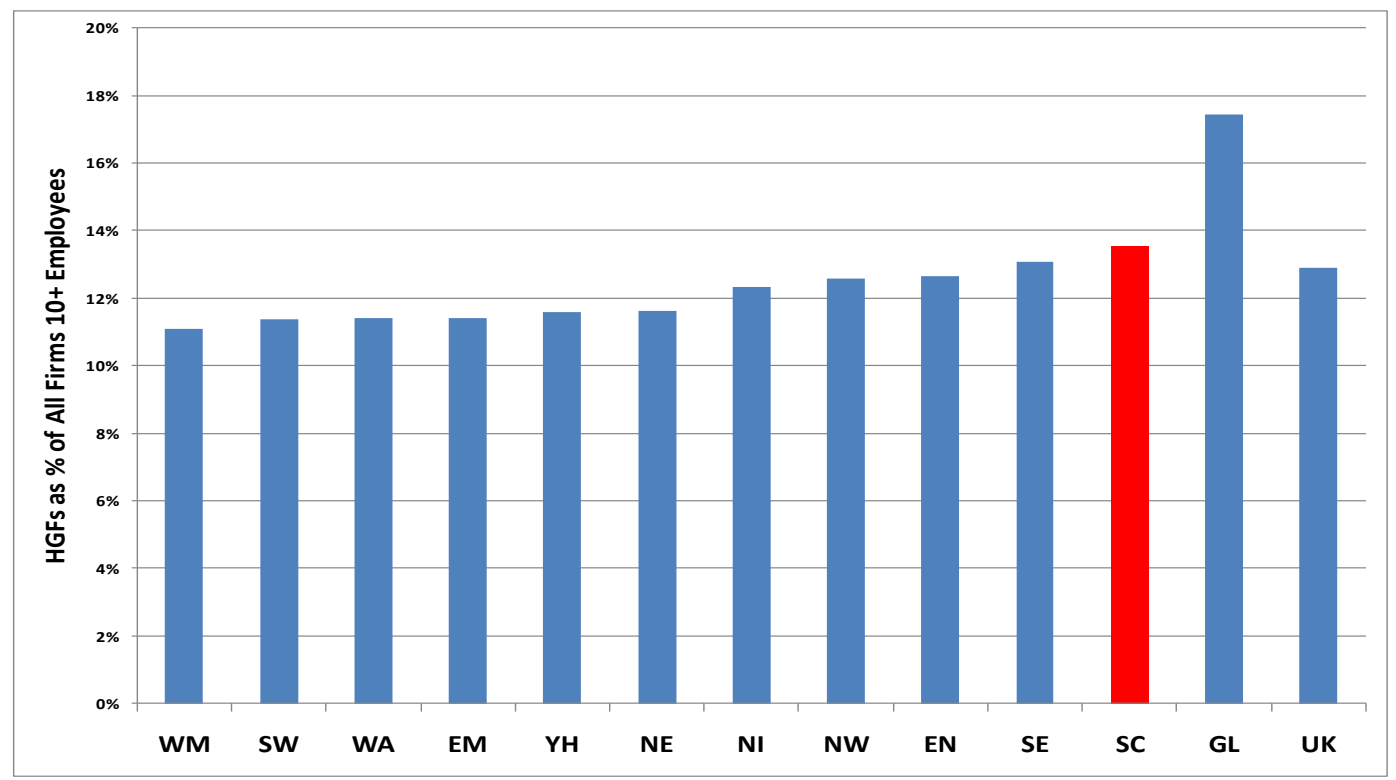

